LETTER

\section{Disturbance of the menstrual pattern after local injection with triamcinolone acetonide}

Local injections of corticosteroids are often used in the treatment of various locomotor disorders. A notable part of injected corticosteroids is absorbed into the circulation. ${ }^{1-}$ This may cause systemic effects. In our practice, a few patients have complained of abundant menstruation after local injection of corticosteroids. A MEDLINE literature search was carried out for the period 1966-1996. Evidence was found that triamcinolone acetonide (TA) influenced menstruation after intramuscular application, ${ }^{9-13}$ but no literature was found about disturbance of the menstrual pattern after intra-articular or periarticular corticosteroid injections and because knowledge of the possible side effect is important for medical practice it was decided to investigate this phenomenon.

Seventy seven premenopausal women (mean age 34.6 (SD 9.0) years) were included who were about to be given a first local injection of TA; 46 intra-articular, 24 in soft tissue (bursa, tendon, tendon sheath), seven epidural. The mean (SD) TA dose was 24.0 (16.5) $\mathrm{mg}$. The lowest dose was $1 \mathrm{mg}$.

Patients were asked to pay attention to the appearance of flushing and any abnormality of the menstrual pattern. No patients were lost for follow up. Median time for follow up was six weeks.

Disturbance in menstruation was noticed by 39 of the 77 women $(50.6 \%)$. The onset of the next menstruation was later than expected in 10 and earlier in 16 patients (table 1). The delay ranged from 1-28 (median 7 ) days and the acceleration from 1-20 (median 9) days. Reduced loss of blood and/or shorter duration of the menstruation was reported by four patients and more loss of blood and/or longer duration of the menstruation by 18 Twenty two $(28.6 \%)$ noted flushing.

Abnormalities of menstruation were significantly less frequent in patients using ora contraceptives $(p<0.05)$. No relation was found between disturbance in the menstruation and age, the occurrence of flushing, dose or site of the injection.

Interpretation of the results must be made with caution because an element of overreporting may be expected when patients are specifically asked to report on flushing and abnormalities in their menstrual pattern. On the other hand, it may be assumed that a part

Table 1 Menstrual pattern of 77 premenopausal women after one injection with triamcinolone acetonide in relation to use of oral contraceptives

\begin{tabular}{|c|c|c|}
\hline & $\begin{array}{l}\text { No oral contraceptives } \\
(n=43)\end{array}$ & $\begin{array}{l}\text { Using oral contraceptives } \\
(n=34)\end{array}$ \\
\hline Menses later than expected & $5(11.6)$ & $5(14.7)$ \\
\hline Menses earlier than expected & $13(30.2)$ & $3(8.8)$ \\
\hline $\begin{array}{l}\text { Reduced loss of blood and/or shorter duration of the } \\
\text { menstruation }\end{array}$ & $3(7.0)$ & $1(2.9)$ \\
\hline $\begin{array}{l}\text { More loss of blood and/or longer duration of the } \\
\text { menstruation }\end{array}$ & $14(32.6)$ & $4(11.8)$ \\
\hline Menses normal & $14(32.6)$ & $24(70.6)$ \\
\hline
\end{tabular}

Percentages are shown in parentheses. Differences significant $\mathrm{p}<0.05$.

of the influence on the menses was not detected if the menstrual pattern was inconstant before the corticosteroid injection.

Disturbance of menstrual pattern after intramuscular injection in patients is well documented. ${ }^{9}{ }^{1013}$ It may be assumed that the process after intra-articular and periarticular application of TA is the same as after intramuscular injection. Although the mechanism involved is not completely elucidated the most probable mode of action is by means of progesterone receptors. ${ }^{14}$ Cross effects between TA and progesterone are documented in both directions. ${ }^{14}{ }^{15}$ Endocrinological analysis after a single intramuscular TA injection given on day one or two of the menstrual cycle revealed suppression of the normal midcycle surge of luteinising hormone and follicle stimulating hormone and disappearance of the subsequent rise in progesterone. ${ }^{11-13}$ In oestrogen primed ovariectomised immature rats it was demonstrated that TA could achieve a surge of luteinising hormone and follicle stimulating hormone three hours after administration. ${ }^{14}$ In both situations the effects appeared to be mediated by changes in hypothalamic gonadotropin releasing hormone concentrations. These contradictory effects could be explained by the moment of the cyclus at which the injections were given. ${ }^{14} \mathrm{~A}$ second mode of action of TA could be a direct effect on the endometrium. In that case, a proliferation of the endometrium could be induced or sustained as long as the blood level is high, and a menstruation follows at the moment the blood level decreases.

The large variability of the effect may be explained by variations in absorption to the central circulation and by differences in the hormonal status. ${ }^{14}$

We recommend that patients be informed about the possibility of menstrual irregularities when a TA injection is given.

JAN M A MENS A NICO DE WOLF BERNARD J BERKHOUT HENK J STAM

Department of Rehabilitation Medicine, Faculty of Medicine and Allied Health Sciences, Erasmus University Rotterdam, PO box 1738 , 3000 DR Rotterdam, the Netherlands
Correspondence to: Dr J M A Mens.

1 Armstrong RD, English J, Gibson T, Chakraborty J, Marks V. Serum methylprednisolone levels following intra-articular injection of methylprednisolone acetate. Ann Rheum Dis 1981;40:571-4.

2 Holden G, Kendall PH. The newer corticosteroids for local injection. Ann Phys Med 1961;6:

3 Koehler BE, Urowitz B, Killinger DW. The systemic effects of intra-articular corticosteroids. J temic effects of intra-articular
Rheumatol 1974;1:117-24.

4 Oka M. Absorption of acetates of hydrocortisone, delta-1-hydrocortisone and cortisone from the joint cavity into the circulation. J Clin Endocrinol Metab 1958;18:755-63.

5 Möllmann HW, Barth J, Haack D, Grüer A, Stroband D, Gyselby G, et al. Comparative studies on the pharmacokinetics and duration of effect of intra-articular application of glucocorticoid crystal suspensions. Aktuelle Rheumatol 1986;11:55-60

6 Norcross BM. Intra-articular administration of hydrocortisone in high concentration. JAMA 1958; 167:839-41.

7 Shuster S, Williams IA. Adrenal suppression due to intra-articular corticosteroid therapy. Lancet 1961;ii:171-2.

8 Fuijata T. Systemic effects of intra-articular injection of hydrocortisone acetate. Endocrinol Jpn 1957;4:57-62.

9 Willey RF, Fergusson RJ, Godden DJ, Crompton GK, Grant IW. Comparison of oral prednisolone and intramuscular depot triamcinolone in patients with severe chronic asthma. Thorax 1984;39:340-4.

10 Romanski B, Pawlik K, Wilewska-Klubo T. The use of triamcinolone acetonide in the treatment of severe intrinsic bronchial asthma. Allergol Immunopathol 1978;6:321-4

11 Cunningham GR, Caperton EM Jr, Goldzieher JW. Antiovulatory activity of synthetic corticoids. J Clin Endocrinol Metab 1975;40: $265-7$

12 Cunningham GR, Goldzieher JW, de la Pena A, Oliver M. The mechanism of ovulation inhibition by triamcinolone acetonide. J Clin Endocrinol Metab 1978;46:8-14.

13 Carson TE, Daane TA, Lee PA, Tredway DR, Wallin JD. Effect of intramuscular triamcinolone acetonide on the human ovulatory cycle. Cutis 1977;19:633-7.

14 Brann DW, McDonald JK, Putnam CD, Mahesh VB. Regulation of hypothalamic gonadotropin-releasing hormone and neuropeptide $\mathrm{Y}$ concentrations by progesterone and corticosteroids in immature rats: correlation with luteinizing hormone and folliclestimulating hormone release. Neuroendocrinology 1991;54:425-32.

15 Cuchacovich M, Tchernitchin A, Gatica $\mathrm{H}$, Wurgaft R, Valenzuela C, Cornejo E. Intraarticular progesterone: effects of a local treatment for rheumatoid arthritis. J Rheumatol 1988; 15 . 561-5. 